\title{
Echinoid landings at Mandapam, south-east coast of India with a note on gonadal maturity of two species of sea urchins
}

\author{
R. SARAVANAN, P. JAWAHAR*, T. FRANCIS*, B. AHILAN*, R. SANTHAKUMAR* \\ AND G. GOPAKUMAR \\ Mandapam Regional Centre of ICAR-Central Marine Fisheries Research Institute, Mandapam Camp \\ Ramanathapuram - 623 520, Tamil Nadu, India \\ *Fisheries College and Research Institute, Tamil Nadu Fisheries University, Thoothukkudi - 628 008, Tamil Nadu, India \\ e-mail: thirukkai@gmail.com
}

\begin{abstract}
The sea urchins, belonging to phylum Echinodermata, are a good source of "roe", (gonads) and are being consumed by humans since pre-historic times. In many countries of the world, it is a delicacy among the food items and in retail markets in Japan, it is sold at prices as high as US\$ $600 \mathrm{~kg}^{-1}$. Among the 800 species of echinoids, 105 species are found along the east coast of India and 30 species are recorded along the coast of Tamil Nadu. There is a paucity of information on the biology and ecology of sea urchins and lack of studies on its edibility and palatability. The sea urchin aquaculture called as echiniculture is picking up in subtropics and temperate areas. Importantly, the tropical marine ecosystem of India, which supports diverse flora and fauna is a suitable environment for echiniculture, and the future research needs to be focused to find out the potential species and developing techniques for their aquaculture. The present investigation analysed the landings of echinoderms in the Gulf of Mannar and Palk Bay along the south-east coast of India and also studied the gonadal maturity of two species of sea urchins viz., Salmacis virgulata and Temnopleurus toreumaticus in order to assess their suitability for echiniculture. S. virgulata and T. toreumaticus formed 70 and $30 \%$ respectively of the sea urchins landings at Vedalai and Pampan landing centres. The overall sex ratio of both the species did not deviate significantly from 1:1. In $S$. virgulata the mean monthly gonad index was highest $(9.62 \pm 0.46)$ during September 2014 and for T. toreumaticus, the peak GSI was observed during December 2013. Further studies on captive maturation and breeding are needed to explore the potential of these species for echiniculture.
\end{abstract}

Keywords: Diversity, Echiniculture, Echinoid, Gonadal maturity, Roe, Sea urchins

The phylum Echinodermata, an exclusive marine phylum, comprises approximately 7,000 living species, which are found from the intertidal area to the deep sea bed. Five extant classes of echinoderms are universally recognized viz., Asteroidea (sea stars and starfish), Ophiuroidea (brittle stars, serpent stars and basket stars), Echinoidea (sea urchins, sand dollars and heart urchins), Holothuroidea (sea cucumbers) and Crinoidea (sea lilie and feather stars). There are nearly about 800 echinoid species found in the seas and oceans of the world. These are commercially important organisms and in many countries, aquaculture of echinoids is being carried out to harvest the gonad, known as "roe", which is a delicacy in countries like Japan and France.

Sea urchins are omnivorous animals who live on the ocean floor, feeding on small crustaceans, fish offal, but mainly seaweed (Smith, 1980). They feed on the food material using their teeth "Aristotle lantern" located on the oral side of the test. Edible sea urchins are primary consumers in the coastal rocky-bottom ecosystems and their main diet is marine algae (de Ridder and Lawrence, 1982).
The reproductive system of the sea urchins consists of five lobes in both testis and ovary and are referred to as roe, which serve as the source of eggs or sperm, as well as the main nutrient storage organ (Bruce, 1988). Gonads generally tend to be bright orange in colour in females and light yellow in males (Lewis, 1958). The "roe" of sea urchins have been consumed by humans since pre-historic times in many countries around the world and are considered to be good source of protein and lipids (Chen, 2013). 'Roe' of about 20 species of sea urchins are consumed in the world. It is a prized delicacy in Japan and in retail markets, it is sold at as high as US\$ $600 \mathrm{~kg}^{-1}$. In 2009, the world export of sea urchins crossed US\$ 200 million with Japan importing about 97\% of the global production. In Japan, sea urchins roe are eaten not only as high-priced sushi and sashimi, but also as canned, bottled and pouched products. France is the world's second largest consumer of sea urchins roe, consuming around $1000 \mathrm{t}$ per year (Hagen, 1996).

Among the 800 extant species of echinoids, 150 are found along Indian coastline (Venkataraman and Wafer, 
2005) and among them, 105 species are found along the east coast of India with 30 species recorded along the coast of Tamil Nadu. The Gulf of Mannar and Palk Bay situated along the south-east coast of India, supports a variety of marine flora and fauna due its coral reef based ecosystem. The present investigation aimed to analyse the landings of sea urchins in the Gulf of Mannar and Palk Bay and also to study the gonadal maturity of two species of sea urchins in order to assess their suitability for echiniculture attempts in future.

In the present study, samples of sea urchins species available in Gulf of Mannar and Palk Bay region of the Bay of Bengal were collected for a period of one year (from October 2013 to September 2014) and they were reared in the onshore mariculture facility at the Mandapam Regional Centre of ICAR-Central Marine Fisheries Research Institute (ICAR-CMFRI) in order to analyse the gonadal index. Sea urchins landed by bottom set gill net at Vedalai Landing Centre as well as from trawl landings at Pampan Landing Centre were used for the purpose of quantification and to study species composition. For biological studies, samples collected from bottom set gill net catches were used. Colour of the gonad was used to choose the potential species for gonadal studies. Among the three soft bottom species of sea urchins viz., Temnopleurus toreumaticus (Leske, 1778), Salmacis bicolor L. Agassiz in L. Agassiz \& Desor, 1846, Salmacis virgulata L. Agassiz in L. Agassiz \& Desor, 1846, S. bicolor was neglected owing to its dark grey gonad colour. The gonads of $S$. virgulata and T. toreumaticus are orange yellow in colour, hence highly suitable as a source of edible roe and hence for further aquaculture research studies (Fig. 1). Samples of two sea urchins species viz., $S$. virgulata and $T$. toreumaticus were collected fortnightly for gonadal studies and were sacrificed in order to assess the gonodosomatic index (GSI). Gonad weight was compared with the total drained weight of the whole urchin to arrive

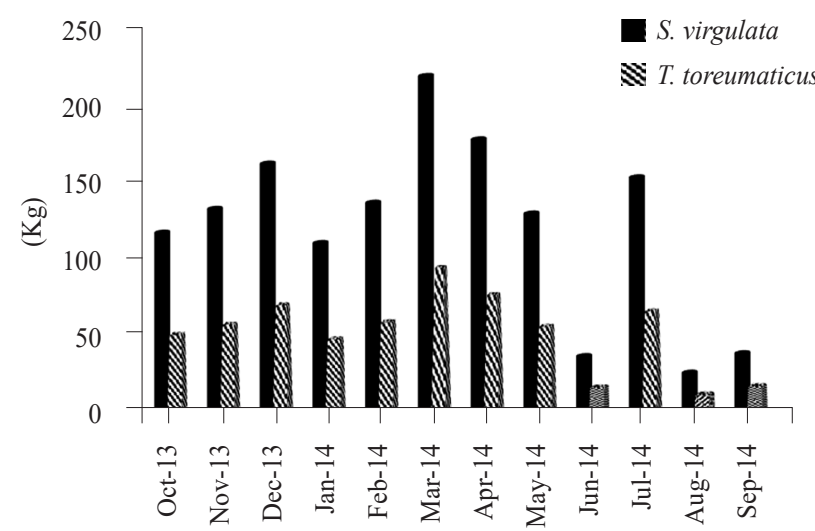

Fig. 1. Temporal variations in the landings of $S$. virgulata and T. toreumaticus from Vedalai Landing Centre (Bottom set gillnet) at the GSI (Muthiga and Jaccarini, 2005; Vaitilingon et al., 2005) as follows:

$$
\text { GSI (\%) }=\frac{\text { Wet weight of gonadi }(\mathrm{g})}{\text { Total weight of sea urchins }(\mathrm{g})} \times 100
$$

The mean GSI of S. virgulata and T. toreumaticus were analysed using one way ANOVA to find the differences in the mean of the GSI are statistically significant for both the species. Tukeys post hoc test was also used to compare the mean GSI of $S$. virgulata and T. toreumaticus. The sex ratio was calculated as the number of male sea urchins divided by the number of females and Chi-squared goodness-of-fit tests was used to see if the overall proportion of males and females deviated significantly from 1:1 (Zhao et al., 2010).

Among the 264 species of echinoderms reported from the Gulf of Mannar, regular sea urchins diversity stands at 24. Among the different species of sea urchins collected viz., Stomopneustes variolaris (Lamarck, 1816), Echinometra mathaei (Blainville, 1825), Temnopleurus toreumaticus (Leske, 1778), Salmacis bicolor L. Agassiz in L. Agassiz and Desor, 1846, Salmacis virgulata L. Agassiz in L. Agassiz and Desor, 1846 and Toxopneustes pileolus (Lamarck, 1816), only two species viz., S. virgulata and T. toreumaticus were available in considerable number in landings throughout the year. Among these, S. variolaris and E. mathaei are rock boring urchins and are not suitable for captive rearing, however their gonads are traditionally consumed by fishermen of Gulf of Mannar. T. pileolus is a toxic sea urchins, having venom and hence it is also not suitable for culture.

The two species of sea urchins viz., S. virgulata and T. toreumaticus formed 70 and $30 \%$ respectively in the sea urchins landings at Vedalai and Pampan landing centres during the study period. The average monthly landing of S. virgulata in trawl and bottom set gill net was 352 and $118 \mathrm{~kg}$ respectively. Whereas, the average monthly landing of T. toreumaticus was 151 and $51 \mathrm{~kg}$ respectively in bottom set gill net landings. Monthly variations in landings of S. virgulata and T. toreumaticus at Vedalai and Pampan landing centres are depicted in Fig. 1 and 2 respectively.

The overall sex ratio of both the species, S. virgulata and T. toreumaticus did not deviate significantly from 1:1. The gonadosomatic index (GSI) which measures the relative changes in weight of the gonads over time, was used to assess sexual maturity in sea urchins as early as 1934 (Moore, 1934) and is based on the assumption that maturation and breeding coincide with maximum gonad weight. The five clear lobes of the ovary in $S$. virgulata and testis in T. toreumaticus are shown in Fig. 3a and b Monthly variation in the GSI of $S$. virgulata during the 12 months study period is presented in Fig. 4. In $S$. virgulata the mean monthly gonad index was highest (9.62 \pm 0.46$)$ during September 2014, and the lowest GSI 


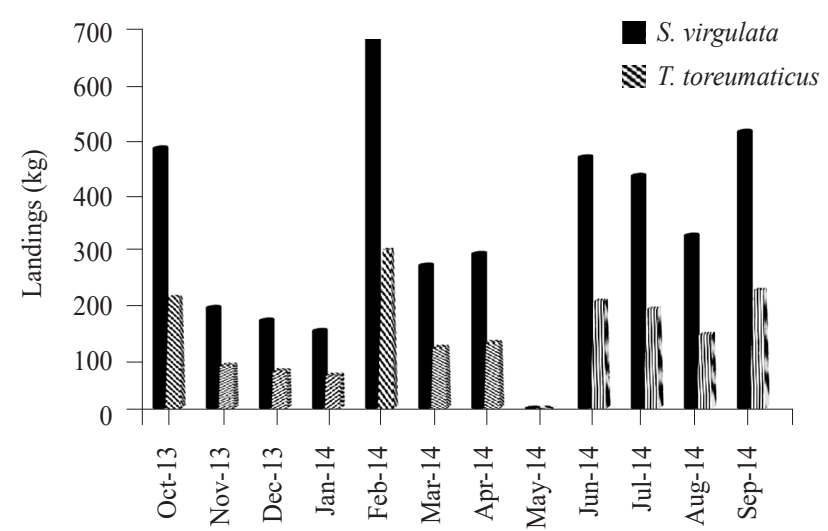

Fig. 2. Temporal variations in the landings of $S$. virgulata and T. toreumaticus from Pampan Landing Centre (Trawl net)

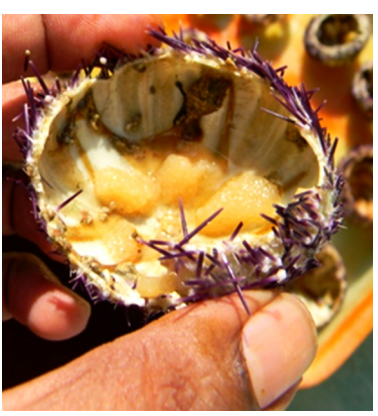

(a)

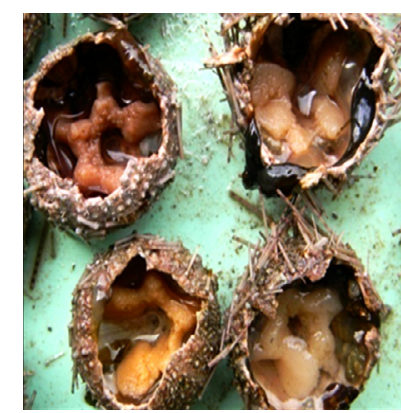

(b)
Fig. 3. Gonads of sea urchins (a) Ovary of Salmacis virgulata; (b) Testes of Temnopleurus toreumaticus

was recorded in December 2013 (2.77 \pm 0.29$)$. Similarly for $T$. toreumaticus, the peak GSI was observed during December 2013 (Fig. 5), which could be the peak spawning season of this species. One way ANOVA of GSI within sea urchin species evidenced statistically significant variation among different months of the study period, however further students ' $t$ ' test revealed that the pattern of variation between the two species was not significantly different. In the present study, in Gulf of Mannar, the populations of $S$. virgulata and $T$. toreumaticus showed one peak spawning period during the north-east monsoon. Further the GSI data revealed that there is a prolonged spawning from October to January for S. virgulata and from November to May for T. toreumaticus.

Species richness was found to be higher in Gulf of Mannar than Palk Bay with respect to sea urchins in spite of the abundance of sea grass bed in Palk Bay. This is mainly attributed to the vast coral reef ecosystem found around the 21 islands in Gulf of Mannar, which is absent in Palk Bay (Venkataraman et al., 2013). However, in India as a whole and Gulf of Mannar in particular, there is no exclusive fishery for sea urchins and a significant amount is landed by commercial fisheries as bycatch. Only in selected pockets

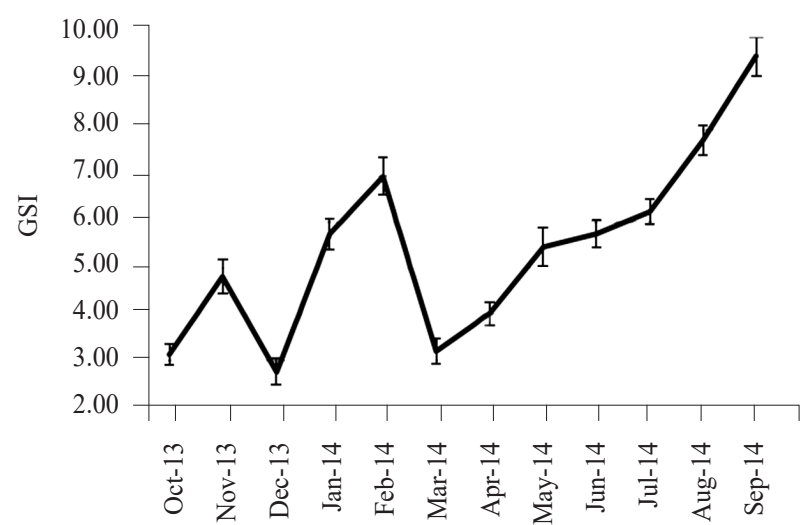

Fig. 4. Temporal variations in the GSI of S. virgulata from Gulf of Mannar

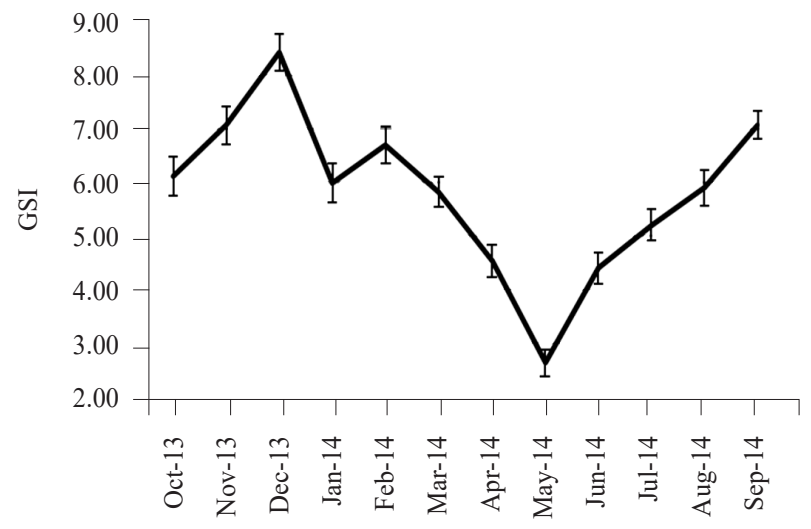

Fig. 5. Temporal variations in the GSI of T. toreumaticus from the Gulf of Mannar

of coastal India, fishers target the collection of sea urchins for their personal culinary use. It has been reported that the fishermen of Muttom coast in Kanyakumari District, south-east coast of India, collect the sea urchins species, Stomopneustes variolaris and sell to star hotels located in neighbouring Thiruvananthapuram City in Kerala (James 1983, 1990 and 1993).

The key factor in the reproductive biology of sea urchins is its GSI, which varies from less than $1 \%$ to as high as $20 \%$ of the total body weight of the urchin in the wild, but for cultured sea urchins, GSI values has been recorded as high as $35 \%$ of the body weight (James and Siikavuopio, 2012). Various factors that influence the GSI are feed availability, environmental conditions (e.g. daylight period, water temperature and presence/absence of water currents) and the reproductive cycle of the urchin. The aquaculture potential of sea urchins is directly related to its GSI. In the present study, the GSI of wild caught $S$. virgulata and $T$. toreumaticus varied from 2 to 10 and there appears to be potential for further research on gonad enhancement in these species through feeding of compounded feeds. 
The global sea urchins trade, dependent on wild harvest since its beginning, has realised its demerits due to overexploitation, which forced various countries to develop a sustainable harvesting method of these resources through wild stocking, land-based culture and sea-based cage culture. Results of the present study indicated that the two species of sea urchins $S$. virgulata and $T$. toreumaticus available along the south-east coast of India could be candidate species for ehinoid aquaculture. The vast coastal waters of the country offer suitable environment for the sea based cultivation of sea urchins in India. The higher market value for sea urchins roe guarantees that any aquaculture attempts would be economical and profitable. However further research on captive maturation and breeding of different species is needed so as to bring the important sea urchins species of our waters in the cultivable species list.

\section{Acknowledgements}

We sincerely acknowledge Dr. A. Gopalakrishnan, Director, ICAR-CMFRI, Kochi for the constant motivation.

\section{References}

Agatsuma, Y. 2014. Population dynamics of edible sea urchins associated with variability of seaweed beds in northern Japan. Aqua-Biosci. Monogr., 7(2): 47-78.

Agatsuma, Y., Sakai, Y. and Andrew, N. L. 2004. Enhancement of Japans's sea urchins fisheries. In. Lawrence, J. M. and Guzman, O. (Eds.), Sea urchins: Fisheries and ecology. EDStech Publication, Lancaster, p. 18-36.

Bruce, C. A. 1988. Sea urchins. INFOFISH Int., 3: 32-34.

Chen, Y. C., Chen, T. Y., Chiou, T. K. and Hwang, D. F. 2013. Seasonal variation on general composition, free amino acids and fatty acids in the gonad of Taiwan's sea urchins Tripneustes gratilla. J. Mar. Sci. Technol., 21(6): 723-732.

de Ridder, C. D. and Lawrence, J. M. 1982. Food and feeding mechanisms: Echinoidea. In: Jangoux, M., Lawrence, J. M. (Eds.) Echinoderm Nutrition, A. A. Balkema Publishers, Rotterdam, p. 57-115.

Hagen, N. 1996. Echinoculture: from fishery enhancement to closed cycle cultivation. World Aquac., 27: 6-19.

James, D. B. 1983. Sea cucumber and sea urchins resources. CMFRI Bull., 34: 85-93.
James, D. B. 1990. Sea urchins roe - A potential resource for export. Seafood Export J., 21(6): 23-36.

James, D. B. 1993. Part II, Sea urchins culture. In: Sea weed, sea urchins and sea cucumber. Handbook on Aquafarming, Marine Products Export Development Authority, Cochin, p. 23-30.

James, P. and Siikavuopio, S. 2012. A guide to the sea urchins reproductive cycle and staging sea urchins gonad samples. ISBN 978-82-7251-976-5, 20 pp.

Lewis, J. B. 1958. The biology of the tropical sea urchins Tripneustes esculentus Leske in Barbados. British West Indies. Can. J. Zool., 36: 607-621.

Moore, H. B., 1934. A comparison of the biology of Echinus esculentus in different habitats. Part I. J. Mar. Biol. Ass. UK, 19: $869-885$

Muthiga, N. A. and Jaccarini, V. 2005. Effects of seasonality and population density on the reproduction of the Indo-Pacific echinoid Echinometra mathaei in Kenyan coral reef lagoons. Mar. Biol., 146: 445-453.

Partos, L. 2011. The future of sea urchins culture. In: www. seafoodsource.com/newsarticledetail.aspx?id=9796 (Accessed 8 April 2013).

Smith, J. 1980. Preliminary study of the sea urchins harvest potential in Placentia and Conception Bays during 1980. Fishing Operations Unit. Department of Fisheries. St. John's. NF, St. John's, Canada.

Vaitilingon, D., Rasolofonirina, R. and Jangoux, M. 2005. Reproductive cycle of edible echinoderms from the southwestern Indian Ocean I Tripneustes 176 gratilla L. (Echinoidea, Echinodermata). Western Indian Ocean. J. Mar. Sci., 4: 47-60.

Venkataraman, C., Venkararaman, K., Rajkumar, R., Shrinivaasu, S., Padmanaban, P., Paramasivam, K. and Sivaperuman, C., 2013. Diversity and distribution of echinoderms in Palk Bay and Gulf of Mannar Biosphere Reserve, Southern India. In: Venkataraman, K., Sivaperuman, C. and Raghunathan, C., (Eds.), Ecology and conservation of tropical marine faunal communities, Springer, Londons, p. 197-212. DOI: 10.1007/978-3-642-38200-0_13.

Venkataraman, K. and Wafer, M. 2005. Coastal and marine biodiversity of India. Indian J. Mar. Sci., 34(1): 54-75.

Zhao, C., Zhang, W., Chang, Y. and Liu, P. 2010. Test and gonad characteristics in different genders of cultivated sea urchins (Strongylocentrotus intermedius, Agassiz): first insight into sexual identification. Afr. J. Biotechnol., 9(44): 7560-7563. 